\title{
電離箱形状や使用頻度の違いによる 事前照射の測定值への影響
}

稫床技術

論文受付

2011 年 12 月 15 日

論文受理

2012 年 6 月 3 日

Code No. 815

\section{下野哲範 ${ }^{1}$ 南部秀和 ${ }^{2}$ 松原孝祐 ${ }^{3}$ 越田吉郎 ${ }^{3}$ 五味 勉 ${ }^{4}$}

\author{
${ }^{1}$ 星ヶ丘厚生年金病院放射線部 \\ 2 近畿大学医学部奈良病院放射線部 \\ 3 金沢大学医薬保健研究域保健学系 \\ 4 北里大学医療衛生学部医療工学科
}

\section{緒 言}

放射線治療に扮ける電離箱の高エネルギー光子ビー ムに対するレスポンスは照射からの経過時間や線量に よって変化を示すことがある1．このようなレスポンス の変化を強制的に解消する日常的な対応策として, 線 量測定プロトコルである米国物理学会(American Association of Physicists in Medicine; AAPM) Task Group 51 report(TG-51)や国際原子力機関 (International Atomic Energy Agency; IAEA)Technical Report Series No. 398（TRS-398）は安定した測定值を得るために 2 時
間前の電位計への電源投入と 2〜 $5 \mathrm{~Gy}$ の事前照射を 行うことを推奨している2,3)。またRamsey ら ${ }^{4)}$ の極性 効果補正の報告では電離箱の印加電圧を反転させた 後，安定した測定値を得るために一定量の線量を事前 に照射する方法が報告されている。一方，DeBlois ${ }^{5) や ~}$ Derikum $ら^{6}$ の報告では電離箱への事前照射の不足が測 定誤差を生じることが指摘されている. McCaffrey ら は事前照射における電離箱のレスポンスはステムへの 照射が大きく影響し，絶縁体の材質や中心電極の遮蔽 範囲などの電離箱の構造で異なることを示した。このよ

\section{Influence on Measurements of Pre-irradiation Due to Differences in Ionization Chamber Shape or Frequency in Use}

\author{
Tetsunori Shimono, ${ }^{1 *}$ Hidekazu Nambu, ${ }^{2}$ Kosuke Matsubara, ${ }^{3}$ Kichiro Koshida, ${ }^{3}$ and Tsutomu Gomi ${ }^{4}$ \\ ${ }^{1}$ Department of Radiology, Hoshigaoka Koseinenkin Hospital \\ ${ }^{2}$ Department of Radiology, Nara Hospital Kinki University Faculty of Medicine \\ ${ }^{3}$ Department of Quantum Medical Technology, Faculty of Health Sciences, Kanazawa University \\ ${ }^{4}$ School of Allied Health Sciences, Kitasato University
}

Received December 15, 2011; Revision accepted June 3, 2012

Code No. 815

\section{Summary}

Ionization chamber measurements in radiation therapy should be repeatedly performed until a stable reading is obtained. Ionization chambers exhibit a response which depends on time elapsed since the previous irradiation. In this study, we investigated the response of a set of two Farmer-style, one Plane parallel, and seven small ionization chambers, which are exposed to 4, 6, 10, and $14 \mathrm{MV}$. The results show that Farmerstyle and Plane parallel ionization chambers settle quickly within 9-20 min. On the other hand, small ionization chambers exhibit settling times of 12-33 min for 6, 10, and $14 \mathrm{MV}$. It will take longer for a settling time of $4 \mathrm{MV}$. The settling time showed time dependent irradiation. The first reading was up to $0.76 \%$ lower in the Farmer-style and Plane parallel ionization chambers. The small ionization chambers had a $2.60 \%$ lower first reading and more gradual response in reaching a stable reading. In this study, individual ionization chambers can vary significantly in their settling behavior. Variation of the responses on ionization chambers were confirmed not only when radiation was not used for a week but also when it was halted for a month. Pre-irradiation of small ionization chambers is clearly warranted for eliminating inadvertent error in the calibration of radiation beams.

Key words: pre-irradiation, ionization chamber, response, dosimetry

*Proceeding author 
Table 1 Characteristics of Farmer-type and small-cylindrical type ionization chambers used for the study

\begin{tabular}{lccccc}
\hline \hline Chamber & $\begin{array}{c}\text { Cavity volume } \\
\left(\mathrm{cm}^{3}\right)\end{array}$ & Thimble & Electrode & Insulator & $\begin{array}{c}\text { Unguarded } \\
\text { distance }(\mathrm{mm})\end{array}$ \\
\hline NE 2571 & 0.68 & graphite & aluminum & PCTFE (KEL-F) & 26 \\
PTW 30001 & 0.6 & PMMA & aluminum & PE/PF & 0 \\
PTW 23323 & 0.1 & PMMA & aluminum & PE/PF & 0 \\
PTW 31015 & 0.03 & PMMA & aluminum & PE/PF & 0 \\
PTW 31016 & 0.016 & PMMA & aluminum & PE/PF & 0 \\
PTW 31006 & 0.015 & PMMA & steel & PE/PF & 0 \\
CC04 & 0.04 & Shonka C-552 & Shonka C-552 & PTFE (teflon) & 0 \\
CC01 & 0.01 & Shonka C-552 & steel & PTFE (teflon) & 0 \\
CC13 & 0.13 & Shonka C-552 & Shonka C-552 & PTFE (teflon) & 0 \\
\hline
\end{tabular}

PMMA; polymethyl methacrylate, PCTFE; polychlorotrifluoroethylene, PE/PF; polyethylene/phenolformaldehyde, PTFE; polytetrafluoroethylene

\section{うに電離箱に事前照射を行うことは測定誤差を低減で} きる一つの方法として考えられている.

近年の定位放射線治療や強度変調放射線治療におい て有効体積 $0.1 \mathrm{~cm}^{3}$ 以下の小型電離箱が線量検証に使 用されている. 小型電離箱は Farmer 形電離箱と比べ長 径も短縮し, 電離容積も非常に小さくなっている。 しか し電離箱壁厚, 集電極やケーブルの直径には大きな変 化はない。これは電離箱空洞体積に対する電極や絶縁 体の体積, ケーブルの導体の比率が Farmer 形電離箱と 比較して小型電離箱のほうが大きいことを意味する。ま た小型電離箱での線量測定ではステムやケーブルへの 照射の影響が顕著になり, 微弱な電離電流を計測する ので注意が必要になる. Farmer 形電離箱への事前照射 の有用性は電離箱構造と関連づけて確立されている. 一方, 有効体積 $0.1 \mathrm{~cm}^{3}$ 以下の小型電離箱のレスポンス や事前照射の測定值への影響に関しては十分に評価が されていないのが現状である.

小型電離箱の測定值の安定性を確保するために測定 器具の安定性, 測定配置の再現性や放射線出力の安定 性に相応の注意が必要となる。したがって電離箱の構 造や加速器からの高エネルギー光子ビームの照射線量 率，照射時間や照射間隔などの測定条件の変化に対す る測定誤差を明確にしておく必要がある ${ }^{8 \sim 10)}$ 。この報告 では小型電離箱の測定值の安定性を電離箱の形状と関 連づけ，放射線治療で使用する小型電離箱での照射直 後のレスポンスの変動ならびに使用頻度の違いによる 事前照射の測定值への影響について検討した.

\section{1. 方 法}

\section{1-1 使用機器および測定条件}

指頭形電離箱, 平行平板形電離箱の 2 種類を対象と した．指頭形電離箱として Farmer 形電離箱を PTW 社
Table 2 Characteristics of parallel-plate type ionization chamber used for the study

\begin{tabular}{llcc}
\hline \hline PPC 40 & Material & Thickness & Diameter \\
\hline Entrance window & PMMA & $1.18 \mathrm{~g} / \mathrm{cm}^{3}$ & - \\
Body & PMMA & - & - \\
Electrode & graphitised & - & $16 \mathrm{~mm}$ \\
\hline
\end{tabular}

PMMA; polymethyl methacrylate

製 30001 $\left(0.6 \mathrm{~cm}^{3}\right)$ と Nuclear Enterprises 社 製 NE2571 $\left(0.68 \mathrm{~cm}^{3}\right)$ の 2 本ならびに小型電離箱を PTW 社製 $23323\left(0.1 \mathrm{~cm}^{3}\right), 31015\left(0.03 \mathrm{~cm}^{3}\right), 31016\left(0.016 \mathrm{~cm}^{3}\right)$, $31006\left(0.015 \mathrm{~cm}^{3}\right)$ と Wellhoefer Dosimetry 社 製 CC04 $\left(0.04 \mathrm{~cm}^{3}\right), \mathrm{CC} 01\left(0.01 \mathrm{~cm}^{3}\right), \mathrm{CC} 13\left(0.13 \mathrm{~cm}^{3}\right)$ の 7 本を 用いた $($ Table 1). 平行平板形電離箱はWellhoefer Dosimetry 社製 PPC40 $\left(0.4 \mathrm{~cm}^{3}\right)$ を 1 本用いた(Table 2). 電位計は RAMTEC 1000D(東洋メディック社製)を用 いた。

医療用加速器はマイクロトロン HTM2210(日立メディ コ社製)を使用した，対象とした放射線は $4 \mathrm{MV}, 6 \mathrm{MV}$,

$10 \mathrm{MV}, 14 \mathrm{MV}$ の X 線である. 線量率は $4 \mathrm{MV} の \mathrm{X}$ 線 で 100 モニ夕単位(monitor unit; MU)/min, $6 \mathrm{MV}$ の X線 で $250 \mathrm{MU} / \mathrm{min}, 10 \mathrm{MV}$ と $14 \mathrm{MV}$ の X線で $300 \mathrm{MU} / \mathrm{min}$ とした。

測定用ファントムは校正用水ファントム (501-300 防水 鞘 $1.0 \mathrm{~mm}$, 外寸： $320 \times 320 \times 390 \mathrm{~mm}$, 東洋メデイック社 製)を用い，アイソセンタに電離箱の実効中心を配置 し，ガントリ角度 0 度，照射野 $10 \times 10 \mathrm{~cm}$, 水深 $10 \mathrm{~cm}$ と した．モニ夕単位の設定数は $100 \mathrm{MU}$ とした，測定深で の線量は $4 \mathrm{MV}$ の X 線で $71.6 \mathrm{cGy}, 6 \mathrm{MV}$ で $77.5 \mathrm{cGy}$, $10 \mathrm{MV}$ で $83.0 \mathrm{cGy}, 14 \mathrm{MV}$ で $86.3 \mathrm{cGy}$ となった.

校正用水ファントムは測定の三日前に水を貯留したも のを使用した。電離箱を挿入したファントム内の測定中 


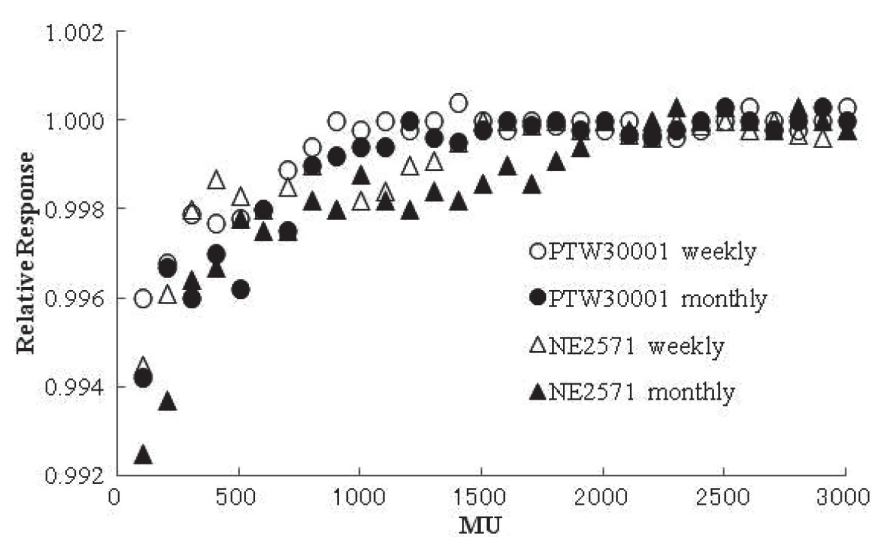

における温度変化はまったくみられなかった。また測定 中の気圧の変化も認められなかった。

加速器の安定性を調べるため半導体検出器を使用し た.DPD510ダイレクト線量計(Wellhoefer Dosimetry 社製)を使用し，EDD-2 型 $\mathrm{p}$ 型シリコンダイオード検出 器(Wellhoefer Dosimetry 社製)をX 線中心軸上の水等 価ファントム[WE タフウォータファントム, $30 \times 30 \mathrm{~cm}$, 積 層形(京都科学社製)]中 $10 \mathrm{~cm}$ の深さに設置した線源一 表面間距離(source-surface distance; SSD) は $90 \mathrm{~cm}$ とし, ファントム表面に垂直に $X$ 線を入射し照射野 $10 \times 10 \mathrm{~cm}$ とした，モニ夕単位の設定数は $100 \mathrm{MU}$ とした.

\section{1-2 測定方法}

\section{1-2-1 各電離箱の安定時間}

各電離箱を用いて測定值の安定時間を調べた。 $4 \mathrm{MV}, 6 \mathrm{MV}, 10 \mathrm{MV}, 14 \mathrm{MV}$ のX線を用いモニ夕 単位数 $100 \mathrm{MU}$ とし連続的に測定を繰り返した。測定 を開始した時間を 0 とし，測定を停止した時間に電位計 の指示值を読んだ，各測定開始時間の間隔は $4 \mathrm{MV}$ で は 90 秒， $6 \mathrm{MV}, 10 \mathrm{MV}, 14 \mathrm{MV}$ では 60 秒とした。各 電離箱の使用間隔は 1 週間と 1 カ月とした，照射野サイ ズは $10 \times 10 \mathrm{~cm}$ で正負 $300 \mathrm{~V}$ の印加電圧で測定した．測 定值の安定時間は最終測定値より $\pm 0.05 \% の$ 範囲内にす べての測定值が得られた時間とした，Farmer 形，平行 平板形電離箱で測定する際の電位計の測定レンジは Hi レンジ, 小型電離箱はLo レンジとした。すべての測定 值は電位計の読み值 $(\mathrm{nC})$ とした。

\section{1-2-2 事前照射の効果}

各電離箱の安定に要した累積線量を照射したのち, モニ夕単位数 $100 \mathrm{MU}$ を測定間隔 30 秒で連続的に測定 した，今回用いた電離箱の中で PTW31006, CC01, PPC40，PTW30001 を用い，安定に要した累積線量で あるそれぞれ $20 \mathrm{~Gy}, 20 \mathrm{~Gy}, 10 \mathrm{~Gy} ， 9 \mathrm{~Gy}$ を事前照射 し測定した。
Fig. 1 Response of a PTW 30001 and NE2571 ionization chambers (Farmer-type) used weekly and monthly to a constant dose of $4 \mathrm{MV}$ photon beam from a Microtron HTM2210. Ionization chambers were applied with $-300 \mathrm{~V}$. Two chambers were connected to a RAMTEC 1000D electrometer. Two chambers were placed at $10 \mathrm{~cm}$ depth in a field size of $10 \times 10 \mathrm{~cm}$, and the source-detector distance was $100 \mathrm{~cm}$.

\section{1-2-3＼cjkstart線量率依存性}

各電離箱のレスポンスの線量率依存性を調べるために $6 \mathrm{MV}$ のX線において線量率を $50 \mathrm{MU} / \mathrm{min}, 100 \mathrm{MU} / \mathrm{min}$, $250 \mathrm{MU} / \mathrm{min}$ としモニ夕単位数 $100 \mathrm{MU}$ を測定間隔 30 秒で連続的に測定した。

\section{1-2-4 加速器の安定性}

マイクロトロンの出力変動を調べるため DPD510 ダイレ クト線量計, EDD-2 型 $\mathrm{p}$ 型シリコンダイオード検出器を 使用して測定した. $4 \mathrm{MV}$ の X線で線量率を $100 \mathrm{MU} / \mathrm{min}$ とし，100 MU を測定間隔 30 秒で連続的に測定した。

\section{2. 結 果}

\section{2-1 各電離箱の安定時間}

\section{2-1-1 Farmer 形電離箱}

PTW30001 の使用間隔 1 週間と 1 カ月のレスポンスを Fig. 1 に示す. エネルギーは $4 \mathrm{MV} の \mathrm{X}$ 線, 印加電圧 を $-300 \mathrm{~V}$ で測定し, 各測定值を最終測定值に対する比 率で示す。使用間隔 1 週間の初回の測定值は安定した 測定值に対して $0.40 \%$ 低い值を示した，安定する約 13.5 分後(累積投与線量 $900 \mathrm{MU}$ : 以下 $900 \mathrm{MU}$ )に達す るまで測定值は増加傾向を示し $\pm 0.05 \%$ 以内に測定值が 安定した. $6 \mathrm{MV}$ の X 線では初回の測定值は安定した測 定值に対して $0.44 \%$ 低い值を示し約 9.0 分後(900MU)で 安定した(Table 3，4）。また使用間隔 1 カ月の初回の測 定值は安定した測定值に対して $4 \mathrm{MV}, 6 \mathrm{MV}$ の X 線で はそれぞれ $0.58 \%, 0.46 \%$ 低い值を示し，18.0, 12.0 分 後(1200 MU)で測定值は安定した(Table 3，5).

$4 \mathrm{MV}$ ，6 MV のX線におけるNE2571 の安定時間は 使用間隔 1 週間でそれぞれ 22.5 分, 15.0 分 (1500 MU), 使用間隔 1 力月で 30.0 分, 20.0 分 (2000 MU) であっ た. 使用間隔 1 週間ならびに 1 カ月における初回の測定 值は $4 \mathrm{MV}$ の X線でそれぞれ $0.55 \%, 0.75 \%, 6 \mathrm{MV}$ の X 線で $0.51 \% ， 0.53 \%$ 低い值を示した (Table 4, 5).

$4 \mathrm{MV}, 6 \mathrm{MV}$ の X 線に扔ける Farmer 形電離箱のレ 
Table 3 The percentage of decrease in the first reading compared with the stable reading ionization chambers used weekly and monthly

\begin{tabular}{|c|c|c|c|c|c|c|c|c|c|}
\hline \multirow{3}{*}{ Chamber } & \multicolumn{4}{|c|}{ Stable time (4 MV) } & \multirow{3}{*}{ Chamber } & \multicolumn{4}{|c|}{ Stable time (6 MV) } \\
\hline & \multicolumn{2}{|c|}{ Weekly } & \multicolumn{2}{|c|}{ Monthly } & & \multicolumn{2}{|c|}{ Weekly } & \multicolumn{2}{|c|}{ Monthly } \\
\hline & $300 \mathrm{~V}$ & $-300 \mathrm{~V}$ & $300 \mathrm{~V}$ & $-300 \mathrm{~V}$ & & $300 \mathrm{~V}$ & $-300 \mathrm{~V}$ & $300 \mathrm{~V}$ & $-300 \mathrm{~V}$ \\
\hline PTW 30001 & 12.0 & 13.5 & 16.5 & 18.0 & PTW 30001 & 8.0 & 9.0 & 11.0 & 12.0 \\
\hline NE 2571 & 21.0 & 22.5 & 27.0 & 30.0 & NE 2571 & 14.0 & 15.0 & 18.0 & 20.0 \\
\hline PTW 23323 & 16.5 & 18.0 & 21.0 & 22.5 & PTW 23323 & 11.0 & 12.0 & 14.0 & 15.0 \\
\hline PTW 31015 & 25.5 & 27.0 & 30.0 & 33.0 & PTW 31015 & 17.0 & 18.0 & 21.0 & 22.0 \\
\hline PTW 31016 & 24.0 & 27.0 & 30.0 & 33.0 & PTW 31016 & 16.0 & 18.0 & 20.0 & 22.0 \\
\hline PTW 31006 & 33.0 & 36.0 & 39.0 & 42.0 & PTW 31006 & 22.0 & 24.0 & 26.0 & 28.0 \\
\hline $\mathrm{CC} 04$ & 34.5 & 39.0 & 39.0 & 46.5 & $\mathrm{CC} 04$ & 23.0 & 26.0 & 26.0 & 31.0 \\
\hline $\mathrm{CC} 01$ & 36.0 & 40.5 & 45.0 & 49.5 & $\mathrm{CC} 01$ & 24.0 & 27.0 & 30.0 & 33.0 \\
\hline $\mathrm{CC} 13$ & 18.0 & 18.0 & 21.0 & 22.5 & $\mathrm{CC} 13$ & 12.0 & 12.0 & 14.0 & 15.0 \\
\hline PPC 40 & 16.5 & 18.0 & 19.5 & 21.0 & PPC 40 & 11.0 & 12.0 & 13.0 & 14.0 \\
\hline
\end{tabular}

Geometry of the set-up was the same as in Fig. 2. Dose rate for a $4 \mathrm{MV}$ photon beam was $100 \mathrm{MU} / \mathrm{min}, 6 \mathrm{MV}$ photon beam was 250 $\mathrm{MU} / \mathrm{min}$.

Table 4 The percentage of decrease in the first reading compared with the stable reading ionization chambers used weekly

\begin{tabular}{|c|c|c|c|c|c|c|c|c|}
\hline \multirow{3}{*}{ Chamber } & \multicolumn{8}{|c|}{ Applied voltage } \\
\hline & \multicolumn{2}{|c|}{$4 \mathrm{MV}$} & \multicolumn{2}{|c|}{$6 \mathrm{MV}$} & \multicolumn{2}{|c|}{$10 \mathrm{MV}$} & \multicolumn{2}{|c|}{$14 \mathrm{MV}$} \\
\hline & $300 \mathrm{~V}$ & $-300 \mathrm{~V}$ & $300 \mathrm{~V}$ & $-300 \mathrm{~V}$ & $300 \mathrm{~V}$ & $-300 \mathrm{~V}$ & $300 \mathrm{~V}$ & $-300 \mathrm{~V}$ \\
\hline PTW 30001 & $-0.15 \%$ & $-0.40 \%$ & $-0.19 \%$ & $-0.44 \%$ & $-0.23 \%$ & $-0.41 \%$ & $-0.18 \%$ & $-0.39 \%$ \\
\hline NE 2571 & $-0.21 \%$ & $-0.55 \%$ & $-0.31 \%$ & $-0.51 \%$ & $-0.29 \%$ & $-0.55 \%$ & $-0.22 \%$ & $-0.47 \%$ \\
\hline PTW 23323 & $-0.16 \%$ & $-0.41 \%$ & $-0.20 \%$ & $-0.48 \%$ & $-0.18 \%$ & $-0.45 \%$ & $-0.16 \%$ & $-0.40 \%$ \\
\hline PTW 31015 & $-0.20 \%$ & $-0.98 \%$ & $-0.22 \%$ & $-1.03 \%$ & $-0.26 \%$ & $-0.96 \%$ & $-0.16 \%$ & $-1.03 \%$ \\
\hline PTW 31016 & $-0.31 \%$ & $-1.00 \%$ & $-0.28 \%$ & $-1.10 \%$ & $-0.33 \%$ & $-1.05 \%$ & $-0.41 \%$ & $-1.08 \%$ \\
\hline PTW 31006 & $-0.41 \%$ & $-1.40 \%$ & $-0.45 \%$ & $-1.47 \%$ & $-0.39 \%$ & $-1.49 \%$ & $-0.36 \%$ & $-1.41 \%$ \\
\hline $\mathrm{CC} 04$ & $-0.70 \%$ & $-1.78 \%$ & $-0.79 \%$ & $-1.82 \%$ & $-0.79 \%$ & $-1.75 \%$ & $-0.69 \%$ & $-1.79 \%$ \\
\hline $\mathrm{CC} 01$ & $-0.75 \%$ & $-2.34 \%$ & $-0.78 \%$ & $-2.48 \%$ & $-0.70 \%$ & $-2.30 \%$ & $-0.77 \%$ & $-2.36 \%$ \\
\hline $\mathrm{CC} 13$ & $-0.24 \%$ & $-0.65 \%$ & $-0.28 \%$ & $-0.73 \%$ & $-0.31 \%$ & $-0.75 \%$ & $-0.27 \%$ & $-0.68 \%$ \\
\hline PPC 40 & $-0.25 \%$ & $-0.56 \%$ & $-0.22 \%$ & $-0.55 \%$ & $-0.22 \%$ & $-0.55 \%$ & $-0.27 \%$ & $-0.51 \%$ \\
\hline
\end{tabular}

Geometry of the set-up was the same as in Fig. 2. Dose rate for a $4 \mathrm{MV}, 6 \mathrm{MV}, 10 \mathrm{MV}$, and $14 \mathrm{MV}$ photon beams were $100 \mathrm{MU} / \mathrm{min}, 250 \mathrm{MU} / \mathrm{min}, 300 \mathrm{MU} / \mathrm{min}$, and $300 \mathrm{MU} / \mathrm{min}$, respectively.

Table 5 The percentage of decrease in the first reading compared with the stable reading ionization chambers used monthly

\begin{tabular}{|c|c|c|c|c|c|c|c|c|}
\hline \multirow{3}{*}{ Chamber } & \multicolumn{8}{|c|}{ Applied voltage } \\
\hline & \multicolumn{2}{|c|}{$4 \mathrm{MV}$} & \multicolumn{2}{|c|}{$6 \mathrm{MV}$} & \multicolumn{2}{|c|}{$10 \mathrm{MV}$} & \multicolumn{2}{|c|}{$14 \mathrm{MV}$} \\
\hline & $300 \mathrm{~V}$ & $-300 \mathrm{~V}$ & $300 \mathrm{~V}$ & $-300 \mathrm{~V}$ & $300 \mathrm{~V}$ & $-300 \mathrm{~V}$ & $300 \mathrm{~V}$ & $-300 \mathrm{~V}$ \\
\hline PTW 30001 & $-0.12 \%$ & $-0.58 \%$ & $-0.21 \%$ & $-0.46 \%$ & $-0.27 \%$ & $-0.49 \%$ & $-0.20 \%$ & $-0.44 \%$ \\
\hline NE 2571 & $-0.30 \%$ & $-0.75 \%$ & $-0.33 \%$ & $-0.53 \%$ & $-0.32 \%$ & $-0.60 \%$ & $-0.24 \%$ & $-0.59 \%$ \\
\hline PTW 23323 & $-0.29 \%$ & $-0.68 \%$ & $-0.29 \%$ & $-0.59 \%$ & $-0.19 \%$ & $-0.56 \%$ & $-0.19 \%$ & $-0.55 \%$ \\
\hline PTW 31015 & $-0.24 \%$ & $-1.15 \%$ & $-0.23 \%$ & $-1.19 \%$ & $-0.29 \%$ & $-1.12 \%$ & $-0.21 \%$ & $-1.19 \%$ \\
\hline PTW 31016 & $-0.45 \%$ & $-1.20 \%$ & $-0.38 \%$ & $-1.26 \%$ & $-0.36 \%$ & $-1.26 \%$ & $-0.41 \%$ & $-1.29 \%$ \\
\hline PTW 31006 & $-0.65 \%$ & $-1.79 \%$ & $-0.49 \%$ & $-1.67 \%$ & $-0.41 \%$ & $-1.69 \%$ & $-0.39 \%$ & $-1.68 \%$ \\
\hline $\mathrm{CC} 04$ & $-0.90 \%$ & $-2.20 \%$ & $-0.85 \%$ & $-1.99 \%$ & $-0.84 \%$ & $-2.03 \%$ & $-0.71 \%$ & $-1.96 \%$ \\
\hline $\mathrm{CC} 01$ & $-0.98 \%$ & $-2.60 \%$ & $-0.81 \%$ & $-2.59 \%$ & $-0.79 \%$ & $-2.58 \%$ & $-0.79 \%$ & $-2.55 \%$ \\
\hline $\mathrm{CC} 13$ & $-0.39 \%$ & $-0.88 \%$ & $-0.36 \%$ & $-0.84 \%$ & $-0.35 \%$ & $-0.89 \%$ & $-0.29 \%$ & $-0.83 \%$ \\
\hline PPC 40 & $-0.40 \%$ & $-0.76 \%$ & $-0.26 \%$ & $-0.61 \%$ & $-0.24 \%$ & $-0.66 \%$ & $-0.31 \%$ & $-0.59 \%$ \\
\hline
\end{tabular}

Geometry of the set-up was the same as in Fig. 2. Dose rate for a $4 \mathrm{MV}, 6 \mathrm{MV}, 10 \mathrm{MV}$, and $14 \mathrm{MV}$ photon beams were $100 \mathrm{MU} / \mathrm{min}, 250 \mathrm{MU} / \mathrm{min}, 300 \mathrm{MU} / \mathrm{min}$, and $300 \mathrm{MU} / \mathrm{min}$, respectively. 


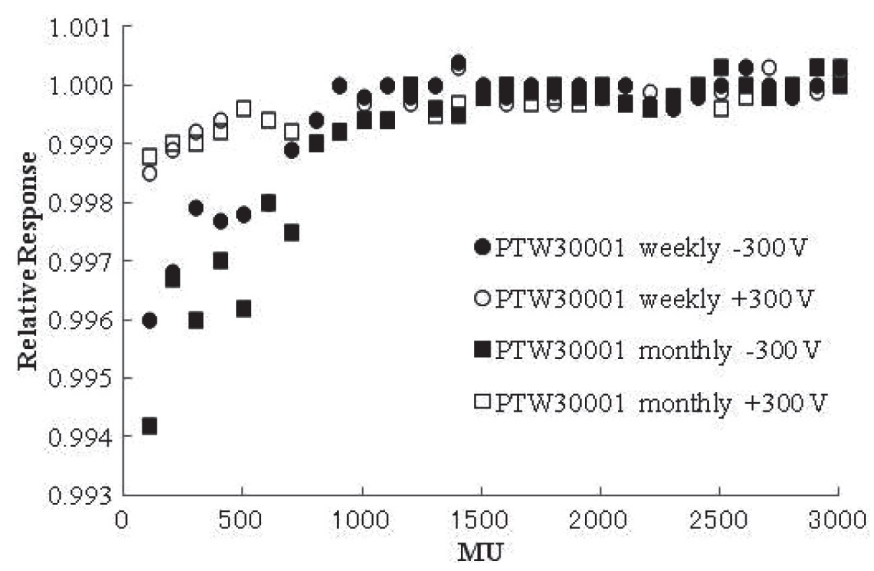

Fig. 2 Response of a PTW 30001 ionization chamber used weekly and monthly to a constant dose of $4 \mathrm{MV}$ photon beam. Measurements were normalized to the final reading of each chamber with applied negative polarity voltage.

PTW 30001 ionization chamber applied negative and positive polarity voltage of $-300 \mathrm{~V}$.

スポンス変動の傾向は測定の繰り返しによる測定値の 上昇傾向がみられた。初回の測定值の低下は使用間隔 1 カ月のほうが使用間隔 1 週間より大きい傾向がみられ た (Table 4，5)。また使用間隔 1 カ月のほうが使用間隔 1 週間より測定值の安定に時間を要した(Table 3)。この ような傾向は Farmer 形電離箱に共通の現象であった.

NE2571 は PTW30001 と比較して初回の測定值の低下が 大きく, 測定值が安定するのに時間を要した. 4 MVの $\mathrm{X}$ 線における Farmer 形電離箱の安定時間は $6 \mathrm{MV}$ に比 べ長時間を要した。初回の測定値は $6 \mathrm{MV}, 10 \mathrm{MV}, 14$ $\mathrm{MV}$ の X 線に扔いても $4 \mathrm{MV}$ と同様な傾向が示され, エネルギー依存性は認めなかった(Table 4).

正負の印加電圧に打ける PTW30001 の使用間隔 1 週 間と 1 カ月のレスポンスを Fig. 2 に示す. 正の印加電圧 では使用間隔 1 週間と 1 カ月の初回の測定值は安定し た測定值に対してそれぞれ $0.15 \%, 0.12 \%$ 低い值とな り, 負の印加電圧での初回の測定值より若干小さい傾 向にあった(Table 4，5)，正の印加電圧では穏やかに安 定值に達したが，負の印加電圧では測定值の増加傾向 がみられた. $6 \mathrm{MV}, 10 \mathrm{MV}, 14 \mathrm{MV} の \mathrm{X}$ 線においても $4 \mathrm{MV}$ と同様な傾向が示され, エネルギー依存性は認め なかった．また正負の印加電圧の違いによる安定時間 の差は小さかった(Table 3).

\section{2-1-2 平行平板形電離箱}

PPC40 平行平板形電離箱の使用間隔 1 週間と 1 カ月 のレスポンスを Fig. 3 に示す.エネルギーは $4 \mathrm{MV} の \mathrm{X}$ 線, 印加電圧を $-300 \mathrm{~V}$ で測定し各測定值を最終測定值 に対する比率で示す。使用間隔 1 週間のPPC40 の初回 の測定值は安定した測定値に対して $0.56 \%$ 低い值を示

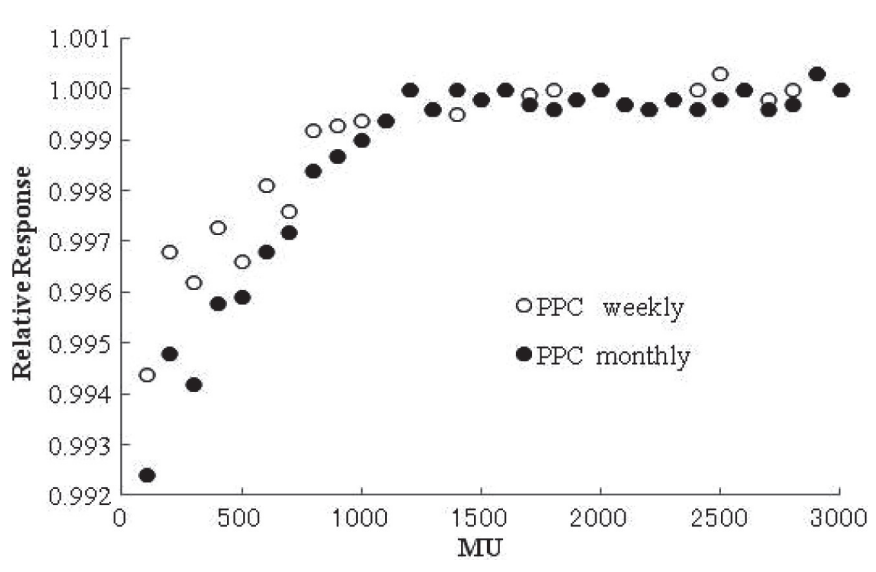

Fig. 3 Response of a PPC40 ionization chamber (parallel-plate type) used weekly and monthly to a constant dose of 4 MV photon beam. Ionization chamber was applied with $-300 \mathrm{~V}$.

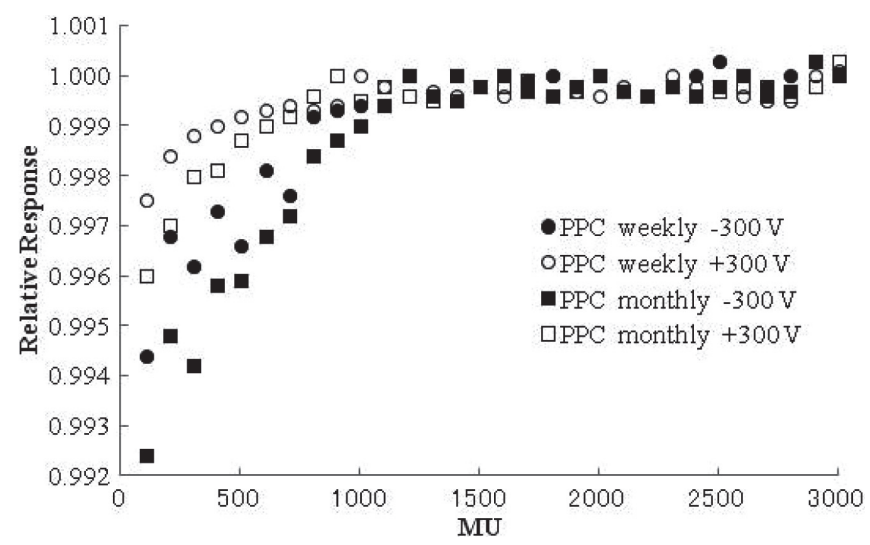

Fig. 4 Response of a PPC40 ionization chamber used weekly and monthly to a constant dose of $4 \mathrm{MV}$ photon beam. Measurements were normalized to the final reading of each chamber with applied negative polarity voltage. PPC40 ionization chamber applied negative and positive polarity voltage of $-300 \mathrm{~V}$.

した(Table 4)，安定する約 18.0 分後(1200 MU)に達す るまで測定值は増加傾向を示した(Table 3)。また使用間 隔 1 カ月では初回の測定值は安定した測定值に対して 0.76\%低い值を示し(Table 5), 21.0 分後 (1400 MU)に測 定值が安定した(Table 3).PPC40 は光子におけるエネ ルギー依存性を認めなかった.

正負の印加電圧における PPC40 の使用間隔 1 週間と 1 カ月のレスポンスを Fig. 4 に示す. 正の印加電圧に比 べ負の印加電圧において安定值に至るまで測定值の増 加傾向がみられた，負の印加電圧における初回の測定 值は正の印加電圧と比較すると若干大きい傾向にあっ た. Farmer 形電離箱と同様に $6 \mathrm{MV}, 10 \mathrm{MV}, 14 \mathrm{MV}$ の X 線においても $4 \mathrm{MV}$ と同様な傾向が示され，エネ ルギー依存性は認めなかった(Table 4，5)，4 MVのX 線におけるPPC40の安定時間は $6 \mathrm{MV}, 10 \mathrm{MV}, 14$ 


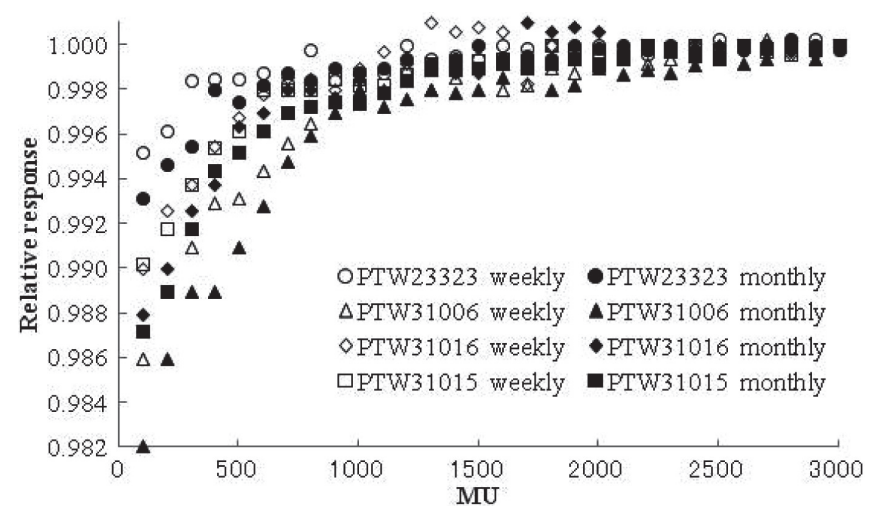

Fig. 5 Response of PTW23323, PTW31006, PTW31016, and PTW31015 ionization chambers (small-cylindrical type) used weekly and monthly to a constant dose of $4 \mathrm{MV}$ photon beam. Ionization chambers were applied with $-300 \mathrm{~V}$.

MVに比べ長時間を要した.

\section{2-1-3 小型電離箱}

小型電離箱の使用間隔 1 週間と 1 カ月のレスポンスを Fig. 5, 6 に示す. エネルギーは $4 \mathrm{MV} の \mathrm{X}$ 線, 印加電 圧を $-300 \mathrm{~V}$ で測定し, 各測定值を最終測定值に対する 比率で示す.PTW23323 の使用間隔 1 週間の安定時間は 18.0 分(1200 MU), PTW31006 は36.0 分(2400 MU), PTW31016は 27.0 分(1800 MU), PTW31015 は 27.0 分 (1800 MU) となった。使用間隔 1 カ月の安定時間は使用 間隔 1 週間と比較して 4.5 分から 6.0 分長くなった (Table 3)。使用間隔 1 週間の初回の測定值は安定した 測定值に対してPTW23323 は $0.41 \%$, PTW31006は $1.40 \%, P T W 31016$ は $1.00 \%, P T W 31015$ は $0.98 \%$ 低 い值を示した(Table 4). 使用間隔 1 カ月の初回の測定 值は使用間隔 1 週間と比較して $0.17 \%$ から $0.39 \%$ 程度 低い傾向にあった(Fig. 5, Table 5)。CC13 の使用間隔 1 週間の安定時間は 18.0 分 (1200 MU), CC01 は 40.5 分 (2700 MU), CC04 は39.0 分 (2600 MU) となった。使用 間隔 1 力月の安定時間は使用間隔 1 週間と比較して 4.5 分から 9.0 分長くなった(Table 3). 使用間隔 1 週間の初 回の測定值は安定した測定值に対して CC13 は $0.65 \%, \mathrm{CC} 01$ は $2.34 \%, \mathrm{CC} 04$ は $1.78 \%$ 低い值を示し た(Fig. 6, Table 4). 使用間隔 1 カ月の初回の測定值は 使用間隔 1 週間と比較して $0.26 \%$ から $0.42 \%$ 低い傾向 にあった(Fig. 6, Table 5)。型電離箱の負の極性にお ける初回の測定值の低下率が Farmer 線量計と比較して 大きかった４ MVの X 線における安定時間は $6 \mathrm{MV}$, $10 \mathrm{MV}, 14 \mathrm{MV}$ に比べ長時間を要した(Table 3). 初回の 測定值は $6 \mathrm{MV}, 10 \mathrm{MV}, 14 \mathrm{MV}$ の X線においても $4 \mathrm{MV}$ と同様な傾向が示されエネルギー依存性は認めなかっ た(Table 4, 5).

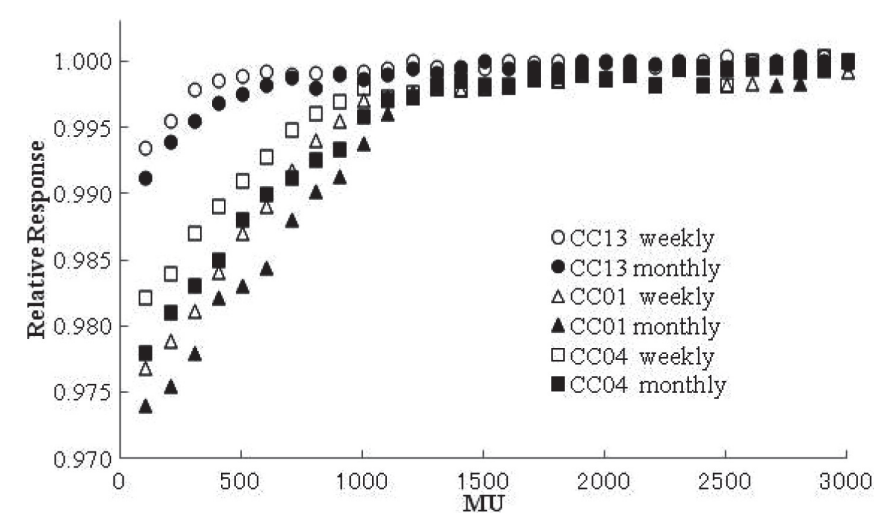

Fig. 6 Response of $\mathrm{CC} 13, \mathrm{CC} 01$, and $\mathrm{CC} 04$ ionization chambers (small-cylindrical type) used weekly and monthly to a constant dose of $4 \mathrm{MV}$ photon beam. Ionization chambers were applied with $-300 \mathrm{~V}$.

正負の印加電圧に扩ける PTW31006，CC01，CC04 小型電離箱の使用間隔 1 週間と 1 カ月のレスポンスを Fig. 7 に示す. PTW31006 における正負の印加電圧の安 定時間の差は正の印加電圧のほうが 3.0 分短くなった. 負の印加電圧と比べ, 正の印加電圧の初回の測定值は 安定した測定値に対し最大 $1.40 \%$ 程度低い值を示した (Fig. 7a，Table 5)。CC01，CC04 においても使用間隔 1 カ月の安定時間が 1 週間と比べ 4.5 分から 9.0 分程度長 くなった．また正の印加電圧の安定時間は負の印加電 圧の安定時間より 4.5 分から 7.5 分程度短くなった (Table 3). 負の印加電圧と比べ, 正の印加電圧の初回 の測定值は安定した測定值に対し CC01は $1.59 \%$, CC04 は 1.08\%低い值を示した(Fig. 7b，c，Table 4)。 初回の測定值は $6 \mathrm{MV}, 10 \mathrm{MV}, 14 \mathrm{MV}$ の X線におい ても $4 \mathrm{MV}$ と同様な傾向が示されエネルギー依存性は 認めなかった。また $4 \mathrm{MV} の X$ 線における安定時間は $6 \mathrm{MV}, 10 \mathrm{MV}, 14 \mathrm{MV}$ に比べ長時間を要した(Table 3). 小型電離箱の初回の測定值低下率はエネルギー依存性 を認めず極性依存を示した，小型電離箱の測定值の変 化は Farmer 形電離箱や平行平板形電離箱とは異なっ た．初回の測定值の低下率は正の印加電圧の測定值に 比べ負の印加電圧のほうが大きくなった，負の印加電 圧での測定值は穏やかに増加し安定值に達したのに対 し，正の印加電圧では安定した測定值に対し最大 $0.6 \%$ の増加を示し安定値に達した，小型電離箱ではこの傾 向は顕著であった。

\section{2-2 事前照射の効果}

電離箱の安定に要した累積線量を照射し事前照射 後のレスポンスをFig. 8 に示した.PTW31006, CC01, PPC40, PTW30001の安定に要した累積線量 

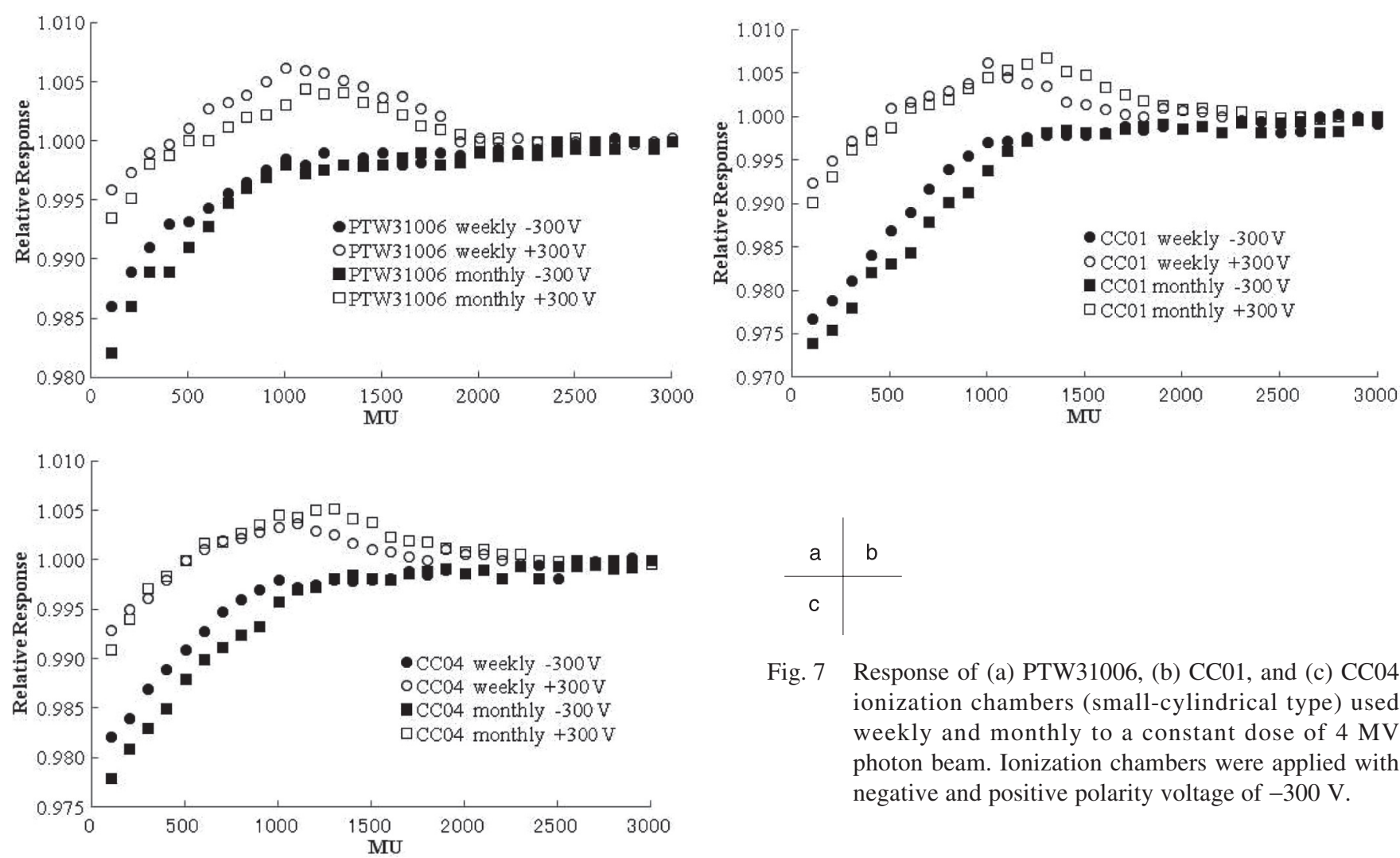

Fig. 7 Response of (a) PTW31006, (b) CC01, and (c) CC04 ionization chambers (small-cylindrical type) used weekly and monthly to a constant dose of $4 \mathrm{MV}$ photon beam. Ionization chambers were applied with negative and positive polarity voltage of $-300 \mathrm{~V}$.

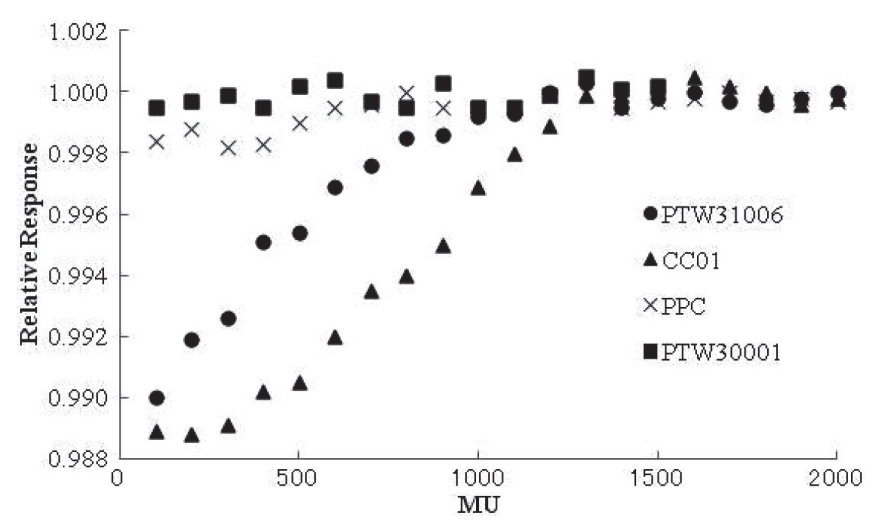

Fig. 8 Response of PTW31006, CC01, PPC40, and PTW30001 ionization chambers pre-irradiated at a cumulative dose with $4 \mathrm{MV}$ photon beam. Cumulative doses for PTW31006, CC01, PPC40, and PTW30001 ionization chambers were $20 \mathrm{~Gy}, 20 \mathrm{~Gy}, 10 \mathrm{~Gy}$, and $9 \mathrm{~Gy}$, respectively.

はそれぞれ約 $20 \mathrm{~Gy}, 20 \mathrm{~Gy}, 10 \mathrm{~Gy}, 9 \mathrm{~Gy}$ であった。 PTW30001 と PPC40 は累積線量を事前照射することに よって初回の測定值より $\pm 0.05 \% の$ 範囲以内にすべての 測定值があった。小型電離箱である PTW31006 と CC01 は事前照射することによって 18.0 分程度で安定值 に達した，次にPTW31006 と CC01 の事前照射に必要 な線量を調べるため, 各電離箱に $25 \mathrm{~Gy}, 20 \mathrm{~Gy}, 10 \mathrm{~Gy}$ を 1 回照射した後のレスポンスを調べた. Fig. 9 からわ

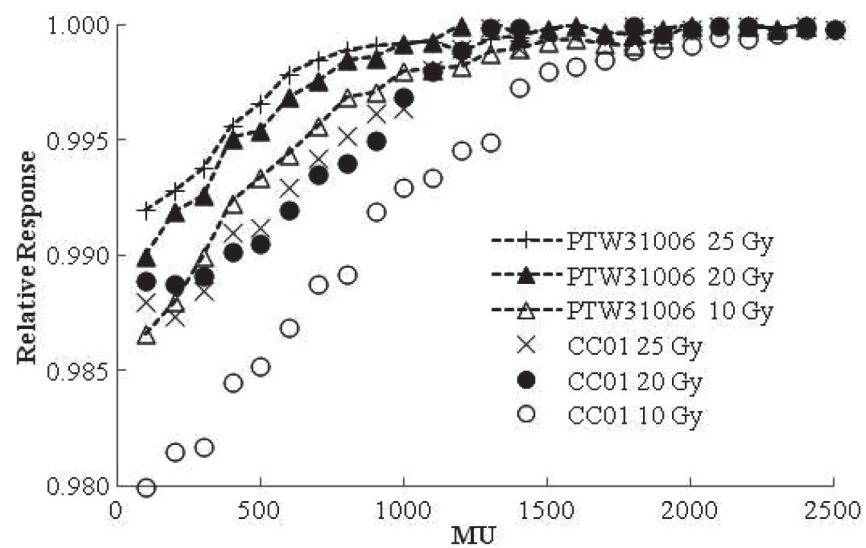

Fig. 9 Response of PTW31006 and CC01 ionization chambers pre-irradiated at a dose with $4 \mathrm{MV}$ photon beam. Doses for PTW31006 and CC01 ionization chambers were 25 Gy, 20 Gy, 10 Gy, respectively.

かるように安定に要した累積線量の $50 \%$ である $10 \mathrm{~Gy}$ の事前照射では初回の測定值の低下率は $20 \mathrm{~Gy}$ の事前 照射時よりも大きかった。また安定值に達するのに PTW31006 は22.5 分, CC01では 27.0 分を要した。安 定に要した累積線量より大線量を事前照射しても電離 箱の安定時間に変化はなかった。

\section{2-3 線量率依存性}

$6 \mathrm{MV}$ の X 線ビームの線量率を $50 \mathrm{MU} / \mathrm{min}, 100 \mathrm{MU} /$ min, $250 \mathrm{MU} / \mathrm{min}$ としたときの小型電離箱 PTW31006 と 

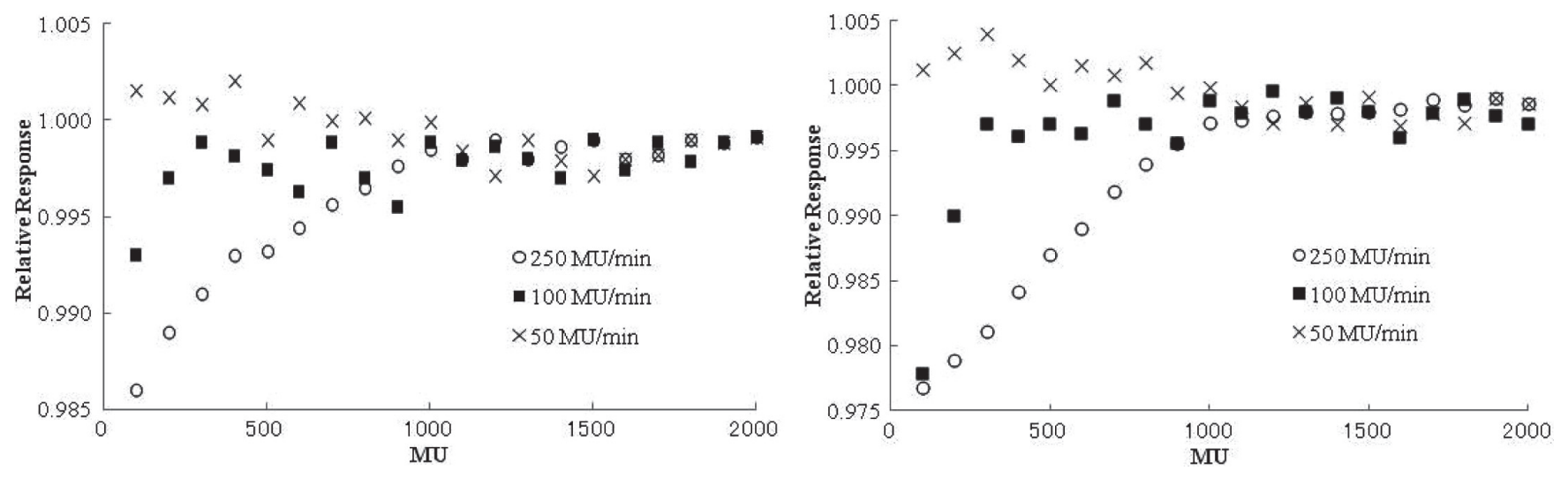

Fig. 10 Response of (a) PTW31006 and (b) CC01 ionization chambers to 6 MV photon beam with various dose rates. The chamber was connected to a RAMTEC $1000 \mathrm{D}$ electrometer and a polarity voltage of $-300 \mathrm{~V}$. The chamber was placed at $10 \mathrm{~cm}$ depth in a field size of $10 \times 10 \mathrm{~cm}$, and the source-detector distance was $100 \mathrm{~cm}$.

CC01 のレスポンスを Fig. 10 に示す. PTW31006とCC01 の測定值は線量率に依存して変化した. $50 \mathrm{MU} / \mathrm{min}$, $100 \mathrm{MU} / \mathrm{min}$ における測定值の変化は $250 \mathrm{MU} / \mathrm{min}$ の場 合と異なり，特に50 MU/min における測定値は安定し た測定值よりも高い值を示した. $4 \mathrm{MV}, 10 \mathrm{MV}, 14$ MVのX線においても $6 \mathrm{MV}$ と同様な傾向を示した.

\section{2-4 加速器の安定性}

EDD-2 型 $\mathrm{p}$ 型シリコンダイオード検出器のレスポン スを Fig. 11 に示す. 初回の測定值から $\pm 0.10 \%$ 範囲以 内にすべての測定值があった. $6 \mathrm{MV}, 10 \mathrm{MV}, 14 \mathrm{MV}$ のX線においても $4 \mathrm{MV}$ と同様な傾向を示した.

\section{3. 考 察}

\section{3-1 電離箱の構造の影響}

放射線治療の線量測定に使用する電離箱のレスポン スの変化があることは知られている，安定した測定值を 得るために, いくつかの線量測定プロトコルには事前照 射を行うことが推奨されている1,2).今回の報告では 種々の要因に㧍ける電離箱のレスポンスの変化ならびに 事前照射の影響を調べた。

電離箱のレスポンスの変化は繰り返し測定することに よって一定值に達する。この傾向は Farmer 形電離箱が 他の電離箱と比較して速やかに安定值に達する傾向が みられた(Fig. 1，2）。しかし同じ Farmer 形電離箱にお いてもPTW30001 とNE2571では安定時間が異なっ た，安定時間が異なる原因として電離箱部の異なる構 造をもつことが考えられる.PTW30001 は電離箱の空洞 部分が完全に保護されているのに対して，NE2571 はス テム内に $26 \mathrm{~mm}$ の非保護の中心電極部が存在する (Table 1)。通常, ケーブルの導体や電離箱の絶縁体が 照射されることによって電荷の移動が生じる．またステ

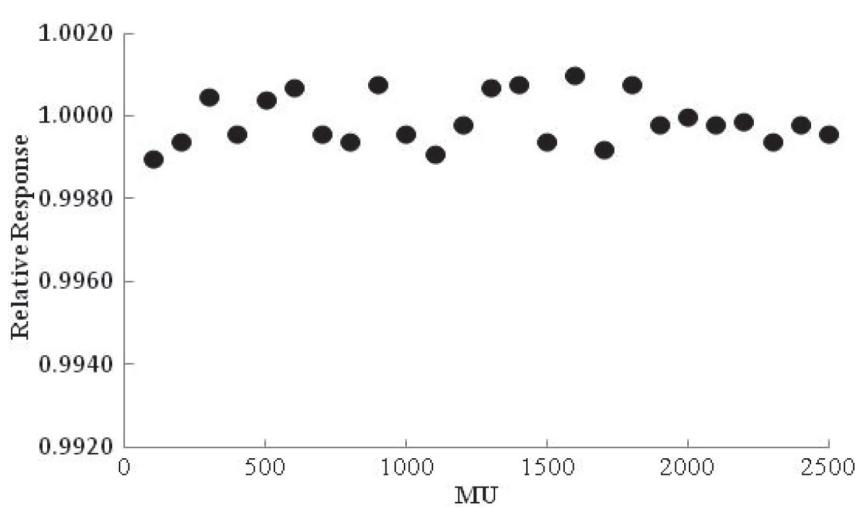

Fig. 11 Response of an EDD-2 silicon diode detector to a constant dose of $4 \mathrm{MV}$ photon beam.

ム内の空洞が電離箱のような作用をすることで電流がも たらす効果がある、ステムの異なる部分が保護された PTW30001 とNE2571 の示すレスポンスの違いは電離 箱部の構造や材質に影響することがわかる。この結果 は個々の電離箱によって異なるレスポンスを特徴づける ものとなる，電離箱のレスポンスの変動を最小限にする ためにはフルガードの電離箱にする必要があることがわ かる. Fowler が $^{8}$ が示したように絶縁体の材質によって レスポンスの変化が生じることは知られている。 今回使 用した電離箱の絶縁体の材質であるポリマは放射線に 対して安定した材質であるため, 電離箱のレスポンス への影響はないと考える。

小型電離箱は他の電離箱とは異なり, 安定した測 定值にいたるまでの傾向に顕著な相違が認められた (Fig. 5〜7). このレスポンスの大きな変化はステムへの 照射の影響であると考えられる．電離箱に接続された ケーブルやコネクタに放射線照射するとその部分が放 射線に対して感度をもつ場合がある(ステム効果)。これ は信号線とアースとの間に微小な空隙があり，その中の 
気体に生じた電離電荷が移動するため生じる擬信号で ある。したがってケーブルやコネクタは極力放射線ビー ムに曝さないよう配慮する必要がある。電離箱のレスポ ンスはステム内部の構造や照射範囲によって異なる。こ のレスポンスの変化を小さくするためフルガードの電離 箱や電離箱の中心電極を囲む絶縁体に amber を使用す ることがある7!

Farmer 形電離箱や平行平板形電離箱の初回の測定 值の低下率は負の印加電圧で - 0.2 - $0.5 \%$ 程度大きく なった. 小型電離箱の負の印加電圧における初回の測 定值の低下率の差は強調され $-0.3 \sim-1.7 \%$ となった。

Farmer 形電離箱と小型電離箱のレスポンスの安定時間 に差が生じたのは電離容積の影響が考えられる。小型 電離箱の空洞容積は Farmer 形電離箱に比べ小さくなつ ているが電離箱壁厚, 絶縁体の体積やケーブルの導体 などの比率は Farmer 形電離箱と比べて小型電離箱のほ うが大きい. そのためステムやケーブル, 漏れ電流など にかかわる影響が大きくなる。電離箱の初回の測定值 の低下現象は電離箱の種類やエネルギー, 使用頻度に 関係なくみられる現象である。また微弱な電離電流を計 測する小型電離箱は電離箱やケーブル，電位計を一体 のシステムとして考える必要がある。今回使用した電位 計(RAMTEC 1000D)に接続するケーブルにおいても静 電容量が発生し，電離箱のレスポンスの安定時間に影 響を与える可能性がある。今回使用した電位計の測定 系のコンデンサはリセット後, 数十秒で放電する。電位 計の誘電吸収も短時間で収まるが測定系の電気的な影 響に注意が必要である。またケーブルを巻いた状態で 長期間保管しているとケーブルを伸ばした際に摩擦や ケーブルテンションの変化によって安定時間に影響を与 える可能性もある(摩擦電気効果).ケーブルへの照射 の影響は Farmer 形電離箱ではあまり問題にならないが 小型電離箱では照射野内に含まれるケーブルの長さに よって測定值に変化が生じる，測定精度を高くするため には照射野内に含まれるケーブルの長さを最短にする 必要がある。したがって小型電離箱のレスポンスは照 射野の大きさに影響するのがわかる.

\section{3-2＼cjkstart印加電圧の極性の影響}

平行平板形電離箱(PPC40) は正の印加電圧では速や かに安定值に達したが, 負の印加電圧では安定值に達 する速さが穏やかであった(Fig. 3，4)。これは極性効果 の影響と考えられる。通常，集電極が小さいFarmer 形 電離箱ではあまり問題ではないが安定值に至るまでは 比較的に集電極が大きな平行平板形と同様に注意を要 する。型電離箱の初回の測定值低下率は極性依存を
示した．また正負の印加電圧の極性で測定值のレスポ ンスの飽和傾向に顕著な差がみられた(Fig. 7)。型電 離箱は極性効果の補正において注意が必要である。極 性効果は絶縁体の材質などに対する絶縁体中での放射 線によって誘導される電流の依存性によることが知られ ている10)．また集電極の大きさばかりでなく，形状や材 質によっても効果が異なる，極性効果の補正を行う際， 測定值の変化する傾向が正負の極性で異なる場合は測 定のタイミングを合致させなければならない．したがっ てイオン収集効率や極性効果に対する補正係数の算出 や加速器のモ二夕線量計の校正においては電離箱のレ スポンスに留意した条件で測定することが必要である。

\section{3-3 線量率の影響}

$\mathrm{X}$ 線ビームに対する小型電離箱のレスポンスにおい て線量率依存性がみられ，特に50 MU/分に扮ける測 定值は安定した測定值よりも高い值を示した(Fig. 10). 安定した測定值に至るまでの電離箱のレスポンスは線 量率によって異なる．また照射時間に依存することも考 えられる，今回の測定では $100 \mathrm{MU} /$ 回と一定とした が，線量率を変化させることによって照射時間も変化す る. $50 \mathrm{MU} /$ 分, $100 \mathrm{MU} /$ 分, $250 \mathrm{MU} /$ 分の線量率での 照射時間はそれぞれ 2 分, 1 分, 24 秒である。電離箱 内の絶縁体で発生する過渡漏れ電流は照射時間に依存 する，と仮定すると長時間の照射は短時間の照射に比 べ多いと考えられる. Farmer 形電離箱と比べ低感度の 小型電離箱を用いた場合, 線量計システムの漏れ電流 によって照射中の収集電荷を低下させる，その程度は 測定に要した時間によって影響を受ける。

\section{3-4 電離箱の使用頻度の影響}

今回調べた電離箱において使用間隔 1 カ月の電離箱 は使用間隔 1 週間のものと比較し安定值に到達する時 間を多く要した。電離箱の使用頻度が毎月または頻繁 に使用されない場合の線量測定への影響は重要であ る. 各電離箱における初回の測定值と安定した測定值 との差は無視できない相違であると考えられる，特に小 型電離箱の測定值が Farmer 形や平行平板形電離箱と 異なる挙動を示す可能性がある。本研究において測定 の分析範囲が限定的であったため, 電離箱の使用頻度 の差が安定時間に及ぼす影響の原因を断定するには限 界があった，今後は電離箱に接続されたケーブルやコ ネクタ, 電離箱の保管環境も考慮にいれた調査を検討 する，電離箱は空気コンデンサを検出器とする電離電 荷測定系である．検出部に電荷捕集のために電圧を印 加し, 直列するコンデンサの端子電圧を測定することに 
よって電荷の生成率や積分值を測定する. 高入力イン ピーダンスの測定系であるため, さまざま影響を受けや すいことに配慮して使用する必要がある。同軸ケーブル は信号線がアース線で遮蔽され, 雑音を拾い難い構造 になっている，信号線とアース線を隔てる絶縁体に圧電 性があるので, ケーブルの曲げ伸ばしによって絶縁体 の圧電に起因する雑音が測定に影響する. 積分電荷量 の測定の場合，ケーブルの敷設から測定開始までは十 分な時間が必要である。特に長期間使用している電位 計やケーブルの劣化による影響によって電離箱の安定 に時間を要する。さらに使用頻度の少ない電離箱での 測定值への影響は大きい. また初めて使用する電離箱 も同じように注意が必要である。

\section{3-5 事前照射の影響}

電離箱に安定に要した累積線量を事前に 1 回照射す ることで電離箱の測定值は速やかに安定した. このこと から X 線ビームに対する電離箱のレスポンスの影響を 解消するために事前照射をすることが有効であることが わかる. Farmer 形電離箱や平行平板形電離箱における 事前照射の効果は 9〜10 Gy で速やかに安定した. 今回 の研究で使用した小型電離箱の安定に要した事前照射 の線量は 10〜24 Gy と異なった。電離容積 $0.1 \mathrm{~cm}^{3}$ 程 度の小型電離箱(PTW23323, CC13)は $10 \mathrm{~Gy}$, 電離容積
0.04 0.015 $\mathrm{cm}^{3}$ 程度の小型電離箱 (PTW31015 : $15 \mathrm{~Gy}$, 31016 : 15 Gy, 31006 : 20 Gy と CC01 : 24 Gy, CC04 : $22 \mathrm{~Gy})$ は 15〜24 Gy の事前照射が必要である。線量測 定プロトコルは 2〜 5 Gy の事前照射を行うことを推奨し ている年が，さらに大きな線量が事前照射には必要で ある。

\section{4. 結 語}

電離箱のレスポンスは連続的な測定で変化すること が明確となった，測定開始直後の電離箱の測定值は低 いレスポンスを示し，その低下率は小型電離箱におい て使用間隔 1 週間では最大 $-2.48 \%$, 使用間隔 1 力月で は最大 $-2.60 \%$ を示した. 小型電離箱のレスポンスの変 化は X 線のエネルギーの違いにかかわらず，電離箱の 構造や材質の違いによって生じた。使用間隔 1 力月のよ うな使用頻度の少ない電離箱のレスポンスの影響は重 要である。電離箱への事前照射は明らかに線量測定に おける誤差を取り除くために有効である。校正定数や 測定における補正係数の決定, 高精度な測定を行う場 合は電離箱のレスポンスの変化を把握し線量測定をす ることが必要である。

本論文の要旨は, 第 38 回日本放射線技術学会秋季 学術大会において発表した。

\section{参考文献}

1) Cacak RK, Hendee WR. Chapter 3. Ionization chamber dosimetry. Techniques of radiation dosimetry. Mahesh K, Vij DR (eds), Wiley Eastern Limited, India, 1985: 104-105.

2) Almond PR, Biggs PJ, Coursey BM, et al. AAPM's TG-51 protocol for clinical reference dosimetry of highenergy photon and electron beams. Med Phys 1999; 26(9): 1847-1870.

3) Andreo P, Burns DT, Hohlfeld K, et al. Absorbed dose determination in external beam Radiotherapy. IAEA Technical Report Series 2000; No. 398.

4) Ramsey CR, Spencer KM, Oliver AL. Ionization chamber, electrometer, linear accelerator, field size, and energy dependence of the polarity effect in electron dosimetry. Med Phys 1999; 26(2): 214-219.

5) DeBlois F, Zankowski C, Podgorsak EB. Saturation current and collection efficiency for ionization chambers in pulsed beams. Med Phys 2000; 27(5): 1146-1155.

6) Derikum K. On the polarizing voltage of ionization chambers Recent Developments in Accurate Radiation Dosimetry, AAPM Symp. Proc. No. 13. Medical Physics Publishing, Madison, 2002; 277.

7) McCaffrey JP, Downton B, Shen H, et al. Pre-irradiation effects on ionization chambers used in radiation therapy. Phys Med Biol 2005; 50(13): N121-N133.

8) Liversage WE. The effects of $x$ rays on the insulating properties of polytetrafluoroethylene. Br J Radiol 1952; 25(296): 434-436.

9) Fowler JF, Farmer FT. Conductivity induced in insulating materials by X-rays. Nature 1954; 173(4398): 317-318.

10) Johns HE, Aspin N, Baker RG. Currents induced in the dielectrics of fonization chambers through the action of highenergy radiation. Radiat Res 1958; 9(6): 573-588. 


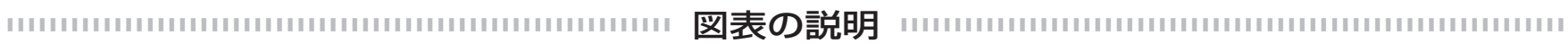

Fig. 1 マイクロトロン HTM2210 に扩り 4 MV-X 線の一定線量に対する週 1 回ならびに月 1 回使用の PTW30001 と NE2571(Farmer 形線量計)のレスポンス

電離箱に対する印加電圧は $-300 \mathrm{~V}$ とした。二つの線量計はRAMTEC1000Dに接続した。二つの線量計は照射野サイズ $10 \times 10 \mathrm{~cm}$ の深さ $10 \mathrm{~cm}$ に配置した，線源検出器間の距離は $100 \mathrm{~cm}$ とした.

Fig. 24 MV-X 線の一定線量に対する週 1 回ならびに月 1 回使用の PTW30001 のレスポンス

測定值は負の極性の印加電圧に扔ける個々の電離箱による最終測定值に対して正規化した. PTW30001に対する印加電圧は正 負の $300 \mathrm{~V}$ とした

Fig. 34 MV-X 線の一定線量に対する週 1 回ならびに月 1 回使用の PPC40(平行平板形)のレスポンス 線量計に対する印加電圧は $-300 \mathrm{~V}$ とした.

Fig. 4 4 MV-X 線の一定線量に対する週 1 回ならびに月 1 回使用の PPC40 のレスポンス

測定值は負の極性の印加電圧に扔ける個々の電離箱による最終測定值に対して正規化した. PPC40に対する印加電圧は正負 の $300 \mathrm{~V}$ とした.

Fig. 54 MV-X 線の一定線量に対する週 1 回ならびに月 1 回使用の PTW23323

PTW31006, PTW31016, PTW31015(小型円筒型)のレスポンス. 線量計に対する印加電圧は-300 V とした.

Fig. 64 MV-X 線の一定線量に対する週 1 回ならびに月 1 回使用の CC13，CC01，CC04(小型円筒型)のレスポンス 線量計に対する印加電圧は $-300 \mathrm{~V}$ とした。

Fig. 74 MV-X 線の一定線量に対する週 1 回ならびに月 1 回使用の(a)CC13，(b)CC01，(c)CC04(小型円筒型)のレスポンス 線量計に対する印加電圧は正負の $300 \mathrm{~V}$ とした.

Fig. 8 4 MV-X 線で PTW31006，CC01，PPC40，PTW30001に累積線量を事前照射したときのレスポンス PTW31006, CC01, PPC40, PTW30001の累積線量はそれぞれ20 Gy, 20 Gy, 10 Gy, 9 Gy とした.

Fig. 94 MV-X 線でPTW31006と CC01に事前照射したときのレスポンス PTW31006, CC01の線量はそれぞれ $25 \mathrm{~Gy}, 20 \mathrm{~Gy}, 10 \mathrm{~Gy}$ とした.

Fig. 10 種々の線量率の 6 MV-X 線に対する(a)PTW31006と(b)CC01 のレスポンス 電離箱に対する印加電圧は $-300 \mathrm{~V}$ とした。二つの線量計は RAMTEC $1000 \mathrm{D}$ に接続し印加電圧は $-300 \mathrm{~V}$ とた。 二つの線量 計は照射野サイズ $10 \times 10 \mathrm{~cm}$ の深さ $10 \mathrm{~cm}$ に配置した。線源検出器間距離は $100 \mathrm{~cm}$ とした.

Fig. 114 MV-X 線での EDD-2 シリコンダイオード検出器のレスポンス

Table 1 この研究で使用した Farmer 形, 小型円筒型電離箱の仕様

Table 2 この研究で使用した平行平板形電離箱の仕様

Table 3 週 1 回ならびに月 1 回使用における線量計の安定した測定值に対する初回の測定值の低下率の百分率 実験配置は Fig. 2 と同様であった. $4 \mathrm{MV}, 6 \mathrm{MV}$ の X線線量率は $100 \mathrm{MU} / \mathrm{min}, 250 \mathrm{MU} / \mathrm{min}$ である.

Table 4 週 1 回使用における電離箱の安定した測定值に対する初回の測定值の低下率の百分率 実験配置は Fig. 2 と同様であった。 $4 \mathrm{MV}, 6 \mathrm{MV}, 10 \mathrm{MV}, 14 \mathrm{MV}$ のそれぞれのX 線線量率は $100 \mathrm{MU} / \mathrm{min}, 250 \mathrm{MU} / \mathrm{min}$, $300 \mathrm{MU} / \mathrm{min}, 300 \mathrm{MU} / \mathrm{min}$ である.

Table 5 月 1 回使用における電離箱の安定した測定值に対する初回の測定值の低下率の百分率 実験配置は Fig. 2 と同様であった。 $4 \mathrm{MV}, 6 \mathrm{MV}, 10 \mathrm{MV}, 14 \mathrm{MV}$ のそれぞれのX 線線量率は $100 \mathrm{MU} / \mathrm{min}, 250 \mathrm{MU} / \mathrm{min}$, $300 \mathrm{MU} / \mathrm{min}, 300 \mathrm{MU} / \mathrm{min}$ である. 